\title{
Analysis of Vegetation and Community Attitude as the Reforestation Efforts at Greenbelt Area of Multipurpose Reservoir of Wonogiri
}

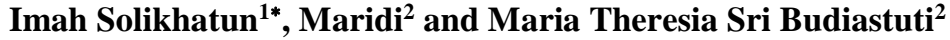 \\ ${ }^{1}$ Student at Master Program of Environmental Science, Universitas Sebelas Maret, Surakarta, Indonesia; \\ ${ }^{2}$ Lecturer at Master Program of Environmental Science, Universitas Sebelas Maret, Surakarta, Indonesia \\ *Corresponding author: imahsolikhatun@student.uns.ac.id
}

\begin{abstract}
Land conversion has caused the function of the greenbelt for reservoir to be less effective. The management of the greenbelt area is needed to maintain the primary function of the reservoir. Therefore, a vegetation analysis in the greenbelt area is necessary to evaluate the condition of the existing vegetation and community attitude to maintain the greenbelt area. This study aims at identifying the current condition of the greenbelt area and the diversity of vegetation as well as the community attitude at the greenbelt area of multipurpose reservoir of Wonogiri. Vegetation sampling was done by purposive sampling using directed line quadrant method, while community attitude sampling was performed using in-depth interviews. This study found 14 species of vegetation in the greenbelt area. The most significant contribution of vegetation species was shown by the Importance Value Index (IVI), with 14 species of tree in which teak (Tectona grandis L.) was the species with the highest IVI value. The species diversity index was 1.15-1.7 and it was included in the medium category. Reforestation efforts can be continued because the vegetation condition has shown moderate stability. Community attitudes towards the greenbelt largely support the existence of management although people still and will use the land without disturbing the existing plants. The reforestation program that has been carried out in the last few years is expected to be able to restore the greenbelt in support of the reservoir function.
\end{abstract}

Keywords: community attitudes; greenbelt; multipurpose reservoir; vegetation analysis

Cite this as: Solikhatun, I., Maridi, \& Budiastuti, M. T. S. (2020). Analysis of Vegetation and Community Attitude as the Reforestation Efforts at Greenbelt Area of Multipurpose Reservoir of Wonogiri. Caraka Tani: Journal of Sustainable Agriculture, 35(2), 228-238. doi: http://dx.doi.org/10.20961/carakatani.v35i2.34616

\section{INTRODUCTION}

Greenbelt is a buffer zone that surrounds reservoirs dominated by vegetation to support the sustainability of reservoir functions (Prabowo et al., 2018). The function of greenbelt area in the reservoir border area is to minimize the siltation of the reservoir due to the erosion that occurs around the reservoir, maintain the soil stability and separate the reservoir from the surrounding land (Rahayu et al., 2016). The greenbelt breakage will shorten dams' age. The rain water from the capturing water area, which has barren wood condition, will bring soil material into the dams so the shallowness cannot be avoided (Prabowo et al., 2018). The ability of vegetation to reduce erosion and sedimentation is influenced by the stage of plant growth, plant height, plant leaf condition, plant density and root system (Ziliwu, 2002). In addition, the functions of greenbeltforming trees are not only to make the reservoir beautiful and cool, but also to maintain the aspects of sustainability, conformity, harmony and balance of natural resources, which will provide environmental services in the form of comfort, freshness, freedom from pollution and noise as

\footnotetext{
* Received for publication September 18, 2019

Accepted after corrections June 6, 2020
} 
well as fauna habitat for next future (Han et al., 2017). Vegetation analysis needs to be done to identify the current condition of the greenbelt. Vegetation analysis is a way of studying the composition of species and shapes or structures of vegetation (Maridi et al., 2015b). The results of the plant vegetation analysis are presented descriptively, particularly dealing with the species composition and its community structure. The presence of vegetation will have a positive impact on the balance of ecosystems on a broader scale and the effect varies depending on the structure and composition of plants that make up the vegetation formation of the area (Cahyanto et al., 2014).

The greenbelt area of multipurpose reservoir of Wonogiri has an area of $\pm 1,653 \mathrm{ha}$, which is located at an elevation of 138.2-140 meter above sea level and surrounds the reservoir in five sub-districts, namely Eromoko, Wuryantoro, Wonogiri, Nguntoronadi and Baturetno (Decree of Director General of State Owned Enterprise of Water Resource Management 1, 2000). The condition of the greenbelt is now alarming, where the pressure caused by the use of land of greenbelt contributes to the land conversion in the greenbelt area into agricultural areas. Conversion of the function of the greenbelt land of reservoir into agricultural land without being realized by the community raises many problems, such as erosion and reservoir sedimentation, which have an impact on the decreasing reservoir capacity. Greenbelt areas need reforestation to replace lost trees due to land conversion.

Reforestation in the greenbelt areas needs to be done to maintain the balance of the ecosystem in the environment by planting trees in barren land. The success of the reforestation process in the greenbelt area is inseparable from the community attitude towards the greenbelt. One solution to maintain vegetation diversity and reservoir function is by reforestation. Reforestation in the greenbelt areas has been carried out from 2014, but not all areas have been planted with seedlings. Seedlings are distributed in stages because the greenbelt covers a large area. In addition to seedling provision for reforestation, community attitude towards greenbelt areas greatly influences the success of reforestation. The attitude of the people who can maintain the preservation of the greenbelt is wanting to maintain and care the greenbelt without damaging and disturbing it.
Community attitude and behavior can be influenced by internal and external factors (Surati, 2014). Community attitude is an evaluative statement, whether or not it is beneficial for the objects, people or events (Tjandra and Tjandra, 2013). Attitude reflects how a person feels about something. When someone says he agrees to the greenbelt regulations, it means he is expressing his attitude towards the greenbelt. Attitude is a continuous organization of motivation, emotions, perceptions and cognitive processes by respecting certain aspects of the environment (Hawkins and Mothersbaugh, 2010).

Vegetation analysis and community attitude as a reforestation effort at greenbelt area of multipurpose reservoir of Wonogiri is one of the initial attempts made to identify the condition of the greenbelt, vegetation diversity and community attitude in the Greenbelt Area of multipurpose reservoir of Wonogiri. It is hoped that the community will have a good attitude in maintaining and utilizing greenbelt without damaging it. This study is highly significant as a basis to provide understanding and new knowledge for communities around the greenbelt area about the greenbelt as a protector and supporter of the sustainability of reservoir functions.

\section{MATERIALS AND METHOD}

The study was conducted in February to March 2019 in the greenbelt area of multipurpose reservoir of Wonogiri, Wonogiri Regency, Central Java Province, Indonesia (Figure 1). Materials and equipment used during the study included basic maps of administration and land use around the multipurpose Reservoir of Wonogiri, GPS, digital cameras, observation sheets, meters, stakes, raffia ropes, stationery and questionnaires.

The determination of sample blocks was based on the approach of field observations and interviews, instead of agricultural land. Based on observations and interviews with the supervisor of greenbelt, 12 stations were obtained with three plots per station. Vegetation sampling was carried out using the plot method in the path, noting all existing vegetation in the form of seedlings, saplings, poles and trees (Hadi et al., 2019). The plot size for trees was $20 \mathrm{~m} \times 20 \mathrm{~m}$; the poles was $10 \mathrm{~m} \times 10 \mathrm{~m}$; saplings was $5 \mathrm{~m} \times 5 \mathrm{~m}$ and seedlings was $2 \mathrm{~m} \mathrm{x} 2 \mathrm{~m}$. 


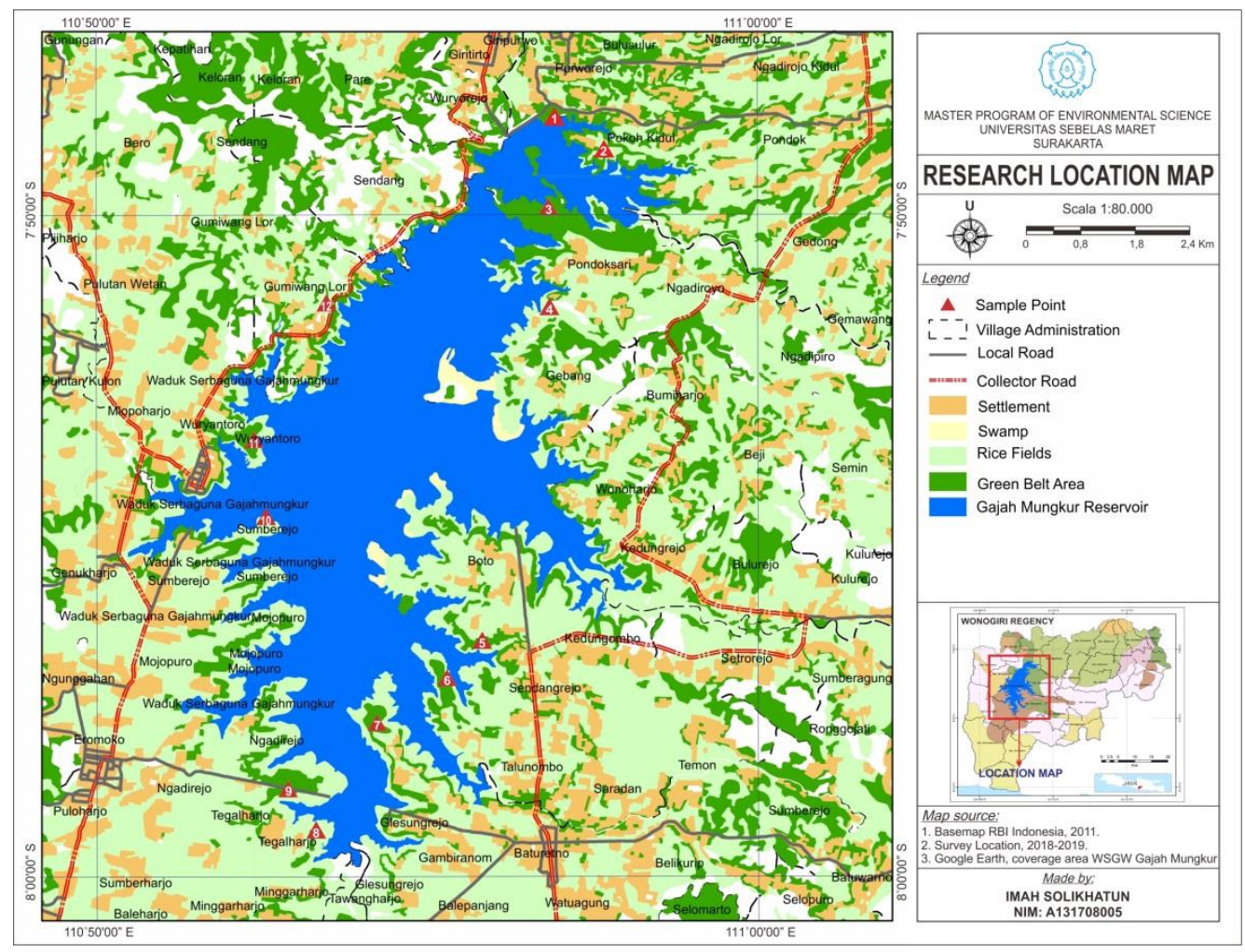

Figure 1. Map of multipurpose reservoir of Wonogiri

Data of vegetation observed in each plot were the number of individuals, species, height, stem diameter at $1.3 \mathrm{~m}$ height at the level of tree, pole, weaning and seedling. Vegetation analysis was carried out after field data had been collected using the quadratic method. Calculations were performed using formulas and procedures in Barbour et al. (1987) and Kusumo et al. (2016), including IVI and Shannon-Wiener's vegetation diversity index. In this study, IVI was obtained from the sum of the relative densities, relative frequencies and relative coverage areas of vegetation at each location. Procedure for calculating IVI and diversity index will be described as follows (Kusumo et al., 2016).

$$
\begin{array}{ll}
\text { Density (KM) } & =\frac{\text { Number of individuals of a type }}{\text { total of plot area }} \\
\text { Relative density (KR) } & =\frac{\text { DM of a species }}{\text { DM of total of all species }} \times 100 \% \\
\text { Frequency (F) } & =\frac{\sum \text { a sub plot is determined by a species }}{\sum \text { total of sub plot }} \\
\text { Relative frequency (FR) } & =\frac{\text { F of a spesies }}{\text { F of total of spesies }} \times 100 \% \\
\text { Dominance (D) } & =\frac{\text { Number of basic planes of a species }}{\text { area of all plot }} \\
\text { Relative dominance (DR) } & =\frac{\text { Domination of a type }}{\text { Domination of all types }} \times 100 \%
\end{array}
$$

The diversity index can be calculated using the Shannon-Wiener Diversity Index formula (Maridi et al., 2015a):

$$
H^{\prime}=-\sum \frac{n i}{N} \log \frac{n i}{N}
$$

Information:

$\mathrm{H}^{\prime}=$ Shannon-Wiener Diversity Index

$\mathrm{ni}=$ Number of each type every-i

$\mathrm{N}=$ Total (overall) number of individuals 
Data of community attitude were obtained from interviews using a questionnaire to the community living around the greenbelt area of 30 people in each sub-district. The samples of respondents were determined using purposive sampling, with the criteria of hamlet residents around the greenbelt area of the multipurpose reservoir of Wonogiri. The data of responses to the questionnaires were analyzed descriptively by grouping the same information to provide answers to the research objectives. Data from the answers to questionnaires of community attitude in the greenbelt area were analyzed using the Gutman Scale (Azwar, 2015).

\section{RESULTS AND DISCUSSION}

Density, frequency and dominance values found at 12 stations in the greenbelt area of the Wonogiri multipurpose reservoir from each species listed in Table 1 indicate striking variations regarding the density of 14 species found. The number of individuals from 14 species at each level of trees, poles, saplings and seedlings was $65,119,83$ and 81 , respectively. The highest value of tree density was obtained by teak (Tectona grandis L.), amounting to $18 ; 200 ; 378$ and 2,708 individuals $\mathrm{ha}^{-1}$ for each level of trees, poles, saplings and seedlings. The highest frequency values obtained by the type of teak at the level of trees, poles, saplings and seedlings were $45.16 \%, 54.84 \%, 41.38 \%$ and $48.15 \%$ correspondingly. The dominance value of each species also varies. The highest values were obtained by the type of teak, which were $7,46,39$ and 75 at each level of trees, poles, saplings and seedlings. These three values were important in the analysis of vegetation because they were related to one another.

Table 1. Value of density, frequency and dominance for each level of tree

\begin{tabular}{|c|c|c|c|c|c|c|c|c|c|c|c|c|}
\hline \multirow{2}{*}{ Type } & \multicolumn{4}{|c|}{ Density } & \multicolumn{4}{|c|}{ Frequency } & \multicolumn{4}{|c|}{ Dominance } \\
\hline & $\mathrm{T}$ & $\mathrm{P}$ & $\mathrm{Sa}$ & $\mathrm{Se}$ & $\mathrm{T}$ & $\mathrm{P}$ & $\mathrm{Sa}$ & $\mathrm{Se}$ & $\mathrm{T}$ & $\mathrm{P}$ & $\mathrm{Sa}$ & $\mathrm{Se}$ \\
\hline $\begin{array}{l}\text { 1. Acacia mangium } \\
\text { Willd. }\end{array}$ & 8 & 8 & 167 & 1,042 & 9.68 & 9.68 & 13.79 & 18.52 & 4 & 2 & 13 & 26 \\
\hline $\begin{array}{l}\text { 2. Albizia chinensis } \\
\text { Merr. }\end{array}$ & 7 & 11 & 33 & 278 & 9.68 & 6.45 & 3.45 & 7.41 & 3 & 2 & 3 & 11 \\
\hline $\begin{array}{l}\text { 3. Albizia saman } \\
\text { Merr. }\end{array}$ & 1 & & & 139 & 3.23 & & & 3.70 & 2 & & & 4 \\
\hline $\begin{array}{l}\text { 4. Anacardium } \\
\text { occidentale L. }\end{array}$ & 4 & 50 & 44 & & 9.68 & 9.68 & 6.90 & & 2 & 11 & 6 & \\
\hline $\begin{array}{l}\text { 5. Dalbergia latifolia } \\
\text { Roxb. }\end{array}$ & 3 & 42 & 100 & 1,250 & 9.68 & 9.68 & 10.34 & 11.11 & 1 & 10 & 8 & 8 \\
\hline $\begin{array}{l}\text { 6. Mangifera indica } \\
\mathrm{L} \text {. }\end{array}$ & 1 & & 11 & & 3.23 & & 3.45 & & 0 & & 1 & \\
\hline $\begin{array}{l}\text { 7. Melaleuca } \\
\text { leucadendra L. }\end{array}$ & 3 & 8 & & & 9.68 & 3.23 & & & 1 & 2 & & \\
\hline 8. Tectona grandis $L$. & 18 & 200 & 378 & 2,708 & 45.16 & 54.84 & 41.38 & 48.15 & 7 & 46 & 39 & 75 \\
\hline $\begin{array}{l}\text { 9. Manihot utilissima } \\
\text { Pohl. }\end{array}$ & & 6 & & & & 3.23 & & & & 1 & & \\
\hline $\begin{array}{l}\text { 10. Swietenia } \\
\text { mahagoni L. }\end{array}$ & & 6 & & & & 3.23 & & & & 1 & & \\
\hline $\begin{array}{l}\text { 11. Annona squamosa } \\
\text { L. }\end{array}$ & & & 67 & 208 & & & 10.34 & 11.11 & & & 4 & 40 \\
\hline $\begin{array}{l}\text { 12. Anthocephalus } \\
\text { macrophyllus } \\
\text { Havil. }\end{array}$ & & & 78 & & & & 3.45 & & & & 5 & \\
\hline 13. Carica papaya $L$. & & & 22 & & & & 3.45 & & & & 2 & \\
\hline $\begin{array}{l}\text { 14. Leucaena glauca } \\
\text { Benth. }\end{array}$ & & & 22 & & & & 3.45 & & & & 2 & \\
\hline Total & 45 & 331 & 922 & 5,625 & 100 & 100 & 100 & 100 & 19 & 76 & 84 & 165 \\
\hline
\end{tabular}

Note: T (tree), P (pole), Sa (sapling) and Se (seedling) 
The frequency value of a species was directly affected by its density and distribution pattern. Value of distribution can only provide information about the presence of certain plants in a plot and cannot yet provide an overview of the individual number in each plot. The difference in the value of the density of each type is due to the differences in reproductive ability, distribution and adaptability to the environment. The spread of plant species in the community is a reaction (response) different from these types of micro-habitat differences. Among the environmental factors that influence the range of plants, soil moisture (water content) is the most influential factor (Martono et al., 2019).

IVI result presented in Table 2 indicates the sum of the relative values of the three parameters (density, frequency and dominance) that had been measured previously, so that the values also varied. Teak was the species with the highest IVI. The levels of trees, poles, saplings and seedlings were 119.67, 176.36, 128.98 and 142.08 , respectively. Some species of trees had the lowest IVI for different categories, including mango for the level of tree (IVI = 5.95), cassava and mahogany for the level of pole (IVI = 6.33), mango for sapling level (IVI $=8.86$ ) and rain tree of saman tree (Albizia saman) for seedlings (IVI $=8.7)$. A high IVI indicates the general role of species in the community (Rahayu et al., 2016), which signifies that teak plants are the typical vegetations of the greenbelt area of Wonogiri multipurpose reservoir. The data in Table 1 and Table 2 show the composition and structure of plants having varying values in each type due to the differences in the characters of each tree. The variations in structure and composition of plants in a community are influenced, among others, by phenology, dispersal and natality (Suyamto, 2011). The success in becoming a new individual is influenced by the different vertices and fecundities of each species so that there are differences in the structure and composition of each species. It reinforces the statement that the IVI provides us with knowledge about the importance of a species in a community or ecosystem (Giliba et al., 2011).

Teak is type of tree having the highest density and frequency value so that it can be considered as a dense and widespread species in almost all research sites. Teak grows best in the tropics or sub-tropics in the temperature range between $9^{\circ} \mathrm{C}$ and $41^{\circ} \mathrm{C}$, the range of rainfall between $1,300 \mathrm{~mm}^{\text {year }}{ }^{-1}$ and 3,800 mm year $^{-1}$ and dry periods between 3 months a year and 5 months a year. In Indonesia, teak is commonly planted in calcareous soils with a slightly acidic to neutral $\mathrm{pH}$, has a deep solum, is well drained and has a clear dry season (Widiatmaka et al., 2015).

Table 2. IVI value and diversity index $\left(\mathrm{H}^{\prime}\right)$

\begin{tabular}{|c|c|c|c|c|c|c|c|c|c|}
\hline \multirow{2}{*}{ No. } & \multirow{2}{*}{ Type } & \multicolumn{4}{|c|}{ IVI } & \multicolumn{4}{|c|}{$\mathrm{H}^{\prime}$} \\
\hline & & $\mathrm{T}$ & $\mathrm{P}$ & $\mathrm{Sa}$ & $\mathrm{Se}$ & $\mathrm{T}$ & $\mathrm{P}$ & $\mathrm{Sa}$ & $\mathrm{Se}$ \\
\hline 1. & Acacia mangium Willd. & 46.56 & 14.39 & 46.90 & 52.86 & 0.31 & 0.09 & 0.31 & 0.31 \\
\hline 2. & Albizia chinensis Merr. & 40.52 & 12.75 & 10.77 & 18.89 & 0.29 & 0.11 & 0.12 & 0.15 \\
\hline 3. & Albizia saman Merr. & 15.04 & & & 8.70 & 0.11 & & & 0.09 \\
\hline 4. & Anacardium occidentale $L$. & 27.37 & 38.95 & 19.33 & & 0.22 & 0.29 & 0.15 & \\
\hline 5. & Dalbergia latifolia Roxb. & 21.42 & 36.03 & 30.86 & 38.19 & 0.17 & 0.26 & 0.24 & 0.33 \\
\hline 6. & Mangifera indica $L$. & 5.95 & & 6.04 & & 0.06 & & 0.05 & \\
\hline 7. & Melaleuca leucadendra $L$. & 23.48 & 8.86 & & & 0.17 & 0.09 & & \\
\hline 8. & Tectona grandis $L$ & 119.67 & 176.36 & 128.98 & 142.08 & 0.37 & 0.30 & 0.37 & 0.35 \\
\hline & Manihot utilissima Pohl. & & 6.33 & & & & 0.07 & & \\
\hline 10. & Swietenia mahagoni $L$. & & 6.33 & & & & 0.07 & & \\
\hline 11. & Annona squamosa $L$. & & & 22.54 & 39.29 & & & 0.19 & 0.12 \\
\hline & $\begin{array}{l}\text { Anthocephalus } \\
\text { macrophyllus Havil. }\end{array}$ & & & 17.91 & & & & 0.21 & \\
\hline & Carica papaya $L$ & & & 8.51 & & & & 0.09 & \\
\hline & Leucaena glauca Benth. & & & 8.14 & & & & 0.09 & \\
\hline & Total & 300.00 & 287.34 & 242.90 & 260.71 & 1.70 & 1.15 & 1.24 & 1.24 \\
\hline
\end{tabular}

Note: T (tree), P (pole), Sa (sapling) and Se (seedling) 
Wonogiri Regency is geographically located between $7^{\circ} 32^{\prime}-8^{\circ} 15^{\prime}$ South Latitude and $110^{\circ} 41^{\prime}$ $111^{\circ} 18^{\prime}$ East Longitude. Based on the climate data from the Wonogiri Meteorological Station (BPP Selogiri), the area around the research site is wet (4-6 months dry). The average rainfall every year is $>2,000 \mathrm{~mm}$ year ${ }^{-1}$. The number of rainy days in the dry season is 5 days and the number of rainy days in the rainy season is 101 days. In 2019, the air temperature was a minimum of $18.26^{\circ} \mathrm{C}$ and a maximum of $36.5^{\circ} \mathrm{C}$, indicating the average temperature of $27^{\circ} \mathrm{C}$ (BPS-Statistics of Wonogiri Regency, 2019). The types of soil found in the greenbelt area of multipurpose reservoir of Wonogiri were dominated by the types of vertisol and alfisol. The existing conditions in the greenbelt area are very supportive for the growth of teak plants and teak is wood commodity with a high economic value, so it is not surprising if it is widely developed by the manager of State-Owned Enterprise of Water Resource Management.

Based on all types of IVI, the diversity index $\left(\mathrm{H}^{\prime}\right)$ is presented in Table 2. The calculation results show that the species diversity indexes in all the plots studied were 1.7 for trees, 1.15 for poles, 1.24 for stakes and 1.24 for seedlings. If using criteria from Barbour et al. (1987), the species diversity index was 1.15-1.7 and thus, included in the medium category. Actually, this condition illustrates that the ecosystem in the greenbelt area of the Wonogiri multipurpose reservoir is moderate for diversity, distribution and stability at a moderate stage. This is due to the reforestation program carried out in areas, where land use has been diverted by management, so that diversity is still at a moderate stage. The diversity shown in the diversity index is an important point in maintaining the balance of processes that run in an ecosystem (Maridi et al., 2015a). The index value of the large contribution needed is supported by a large carrying capacity of the environment towards survival and increasing ecosystem stability (Istomo and Sari, 2019). This result can be interpreted that reforestation that has been done is good and can be continued to achieve high ecosystem stability to support the main function of the greenbelt. Therefore, better management is required because of the high diversity of growth speeds that can affect forest ecosystems (Ufiza et al., 2018).

\section{The community attitude towards the greenbelt area of multipurpose reservoir of Wonogiri}

The community attitude in the greenbelt area can be identified from field observations during in-depth interviews using a closed questionnaire. The community attitude will greatly affect the sustainability of the greenbelt area of multipurpose reservoir of Wonogiri as demonstrated in Table 3. The total number of respondents in this study was 150 people, consisting of 30 people in each sub-district.

Table 3 . The community attitude towards the greenbelt area

\begin{tabular}{|c|c|c|c|c|}
\hline \multicolumn{5}{|l|}{ Community attitude } \\
\hline $\begin{array}{l}\text { Knowledge about greenbelt and land use impacts } \\
\text { (cognitive) }\end{array}$ & \multicolumn{4}{|c|}{ Answer } \\
\hline 1. The definition of greenbelt & Right & $96 \%$ & False & $4 \%$ \\
\hline 2. The main function of greenbelt & Erosion barrier & $82 \%$ & Delimiter & $18 \%$ \\
\hline 3. The main impact of the use of greenbelt land & $\begin{array}{l}\text { Silting } \\
\text { reservoirs }\end{array}$ & $78 \%$ & $\begin{array}{l}\text { Ecosystem } \\
\text { damage }\end{array}$ & $22 \%$ \\
\hline 4. Types of greenbelt vegetation & Annual crops & $76 \%$ & $\begin{array}{l}\text { Production } \\
\text { plants }\end{array}$ & $24 \%$ \\
\hline 5. The causes of changes in greenbelt conditions & Natural factors & $38 \%$ & Human & $62 \%$ \\
\hline $\begin{array}{l}\text { The community attitude towards greenbelts } \\
\text { (affective) }\end{array}$ & \multicolumn{2}{|l|}{ Agree } & \multicolumn{2}{|c|}{ Disagree } \\
\hline 1. The existence of rules to guard & \multicolumn{2}{|l|}{$100 \%$} & \multicolumn{2}{|c|}{$0 \%$} \\
\hline 2. The existence of regulations prohibiting the utilization & $21 \%$ & & \multicolumn{2}{|c|}{$79 \%$} \\
\hline 3. Vegetation management & \multicolumn{2}{|l|}{$80 \%$} & \multicolumn{2}{|c|}{$20 \%$} \\
\hline $\begin{array}{c}\text { The tendency of people to behave } \\
\text { (conative) }\end{array}$ & \multicolumn{2}{|l|}{ Willing } & \multicolumn{2}{|c|}{ Unwilling } \\
\hline 1. Management of the greenbelt area & \multirow{2}{*}{$\begin{array}{l}94 \% \\
30 \%\end{array}$} & \multirow{2}{*}{\multicolumn{3}{|c|}{$6 \%$}} \\
\hline 2. Termination of using the land & & & & \\
\hline
\end{tabular}


The parameters of community attitude or human attitudes include three components, namely cognitive or knowledge that is believed, affective (feeling) and conative or behavioral/behavioral tendencies (Hawkins and Mothersbaugh, 2010; Azwar, 2015). There were five elements of cognitive (knowledge) parameters of the community towards the greenbelt and the questions on the impacts of land use analyzed in this study. The elements cover the definition, main functions, the impact of land use, the type of vegetation and the causes of changes in the greenbelt area.

The results of community cognitive (knowledge) analysis of definitions, main functions, land use impacts and types of greenbelt vegetation were very good. Ninety six percent of the community could correctly define that the greenbelt was a limiting area between community activities and reservoir activities. Eighty two percent of the community could also figure out the main function of greenbelt area to resist erosion occurring around the reservoir. When the greenbelt was not functioning well, the edges of the reservoir would potentially contribute to sedimentation to the reservoir due to erosion.

However, sediment problems in multipurpose reservoir of Wonogiri were caused by erosion in the upstream area of the watershed of Bengawan Solo (Maridi et al., 2015b). The types of plants that should be planted in the greenbelt area of the multipurpose reservoir, according to $75 \%$ of the community, are annual crops such as rice, corn, beans and others. This is so for it was perhaps influenced by economic conditions and favorable land perceptions. Though, this condition threatens the sustainability of reservoir functions, because dense forests and grasses are types of vegetations more effective in resisting erosion compared to intercropping, cotton and corn (Bennet, 1995).

The results of the analysis of the community attitude or affective towards the greenbelt regarding the existence of preserving regulations have shown that the community agreed with greenbelt preservation. In contrast to the existence of regulations prohibiting the use of greenbelt land, as many as $79 \%$ of the community disagreed with the prohibition. This happened, none other than, due to the economic reasons. They were afraid that if they agreed, they would no longer be able to plant rice and thus, their economy would be weakening. Community agreed with the regulation due to their assumption that the greenbelt land was not theirs and they still had rice fields in areas that were not greenbelts. Eighty percent community attitude showed that they corresponded to the management of the greenbelt. It started from agreeing statement of the community to get involved in the management, to consenting statement with the choice of plants benefiting them.

The results of the conative analysis or the analysis of the community tendency to behave in the future whether or not they wanted to maintain the seedlings that had been planted have revealed that as many as $94 \%$ of the community stated their willingness. Inversely, based on the questions related to the termination of land use, as many as $70 \%$ of the community was unwilling. They reasoned that it was possible as long as they would not be interfered with plants planted by the responsible party, State-Owned Enterprise of Water Resource Management. The community attitude tended to be less cooperative towards the sustainability of the function of the greenbelt in supporting the reservoir function. This happens because of the economic factors encouraging them to continue to depend on profitable greenbelt land. The approval for this management can be used as a benchmark that reforestation can be continued.

The analyses of vegetation and community attitude as a reforestation or afforestation effort in the greenbelt area of the Wonogiri multipurpose reservoir included the evaluation of vegetation and community attitude. These two parameters were important in this study to find out the extent of the current condition of vegetation and see whether the community around the greenbelt had the attitude to treat and even maintain the greenbelt that was in the process of reforestation at this time. Reforestation is an effort to make plants of forest tree species in degraded forest areas in the form of empty/open land, reeds, or shrubs to restore forest function (Rusdiana et al., 2017). The types of plants used for reforestation must be adapted to the function of forests, land and local agroclimate conditions.

Conservation and management of natural resources can be successful by identifying firstly the perception and attitude of the community towards the environment (Sari et al., 2018). The attitude itself can be said as someone's evaluative response to an object of evaluation and the 
response can be a good-bad value, positivenegative or like-dislike (Azwar, 2015). The attitude of caring for the environment is a positive or negative support for things that encourage to care for the environment (Sujana and Hariyadi, 2018). If all attitudes and behaviors carried out by the community are negative, the support and efforts to conserve greenbelts (reforestation) will be very low (Setiawan et al., 2017). Therefore, knowing the positive or negative attitude of the community is closely related to the success of reforestation.

The vegetation analysis when viewed from the diversity index was still included in the middle strata, between 1-2. The condition of the reforested plants since 2014 has reached the strata of the pole and sapling. The diversity indexes of stratum and pole strata for the total study locations were 1.24 and 1.15. Analysis of community attitudes ranging from knowledge, attitudes (feelings) and tendency to attitude (behavior) on average showed above $75 \%$ for a few aspects such as plant types and the regulations prohibiting the utilization and willingness to maintain the planted seedlings must be straightened out immediately by State-Owned Enterprise of Water Resource Management so as not to cause more severe damages.

Humans and the environment have interdependent and reciprocal relationships. Interactions between humans and the environment that occur continuously and will affect human behavior towards the environment. Humans attitude and behavior will determine the merits of an environmental condition (Palupi and Sawitri, 2017). Some of the examples are the diversity indexes in the Wuryantoro and Baturetno areas, in which two sub-districts where the research was in succession belonged to the strata of 1.43 and 1.06 and the stakes of 1.63 and 1.36. This indicates that reforestation in the Wuryantoro area has better results than in Baturetno. It is also supported by the attitude of the community in the two subdistricts regarding their willingness to care for seeds, where $100 \%$ of the community in Wuryantoro and $80 \%$ in Baturetno were willing. Twenty percent of the people did not want to take care of the seeds and the bias was indicated to slow down the ongoing reforestation process. This can be overcome by involving influential people in the community to provide an explanation of the conservation so that the effort can run well (Masria et al., 2015). Socialization and guidance from related parties such as agriculture, forestry and government agencies are required to assist the community in using land after reforestation so that no more severe damage occurs (Mayanti et al., 2018).

Behavior is strongly influenced by the environment, specifically, the physical conditions of the environment, economy, culture, politics, etc., which are sometimes even have a greater strength than the individual's own characteristics (Azwar, 2015). The best solution in determining management steps contributing to the community willingness to take care of the greenbelt area is by planting tree seedlings that are profitable for them without neglecting the function of the greenbelt in supporting the sustainability of the reservoir, so that the people do not continue to utilize the greenbelt land. Plants that can be recommended widely available in the greenbelt are fruit plants or production plants that can coexist with other plants, such as coffee. In addition, even if the community continues to use the land continuously, it can be considered for the development of an agroforestry system with land management at minimum. Intensive land management that prioritizes sustainable forest principles protects the ecosystem and it can also increase community income by developing agroforestry systems (Wiryantara et al., 2014). Land management with agroforestry requires the selection of suitable plant species and appropriate silvicultural treatment. Arrangements to maintain light, water and optimum nutrition for each type of constituent are the key to the success of the agroforestry system (Hani and Suryanto, 2014). Further, studies are needed in land suitability, planting distance and type of vegetation, as well as economic studies in the form of economic valuations in the greenbelt area.

Based on the research by Purnomo et al. (2018) about the impact of canopy openness on the abundance of understorey on pine and resin stands, the higher the percentage of canopy cover is, the less the species diversity will be. Thus, the selection of tree species and the spacing between trees must be taken into consideration taking into account that the intensity of sunlight is needed for annual crops. The research by Ariani and Haryati (2018) reported that the optimization of distance (4 m) and periodic hedging of pruning plants that minimize weaknesses in nutrient, light and water competition, the influence of allelopathy, host of fences on major crops are the strategies used to 
take advantage of opportunities to control degradation land, environmentally friendly agriculture and mitigation and adaptation to climate change.

The results of alley cropping system research have shown that SWOT analysis and implementation strategies in the upstream watershed upland can be used as a reference for agroforestry development. The research in terms of economics and agricultural production by Hani and Geraldine (2018) have reported that soybean planted in a staple crop can provide productivity from 0.19 tons ha $^{-1}$ to 0.529 tons ha $^{-1}$ while maize planted among mangrove plants can provide the highest productivity of 1,224 tons $\mathrm{ha}^{-1}$. It is expected that by choosing the right agroforestry system and in accordance with the conditions of the land, it can improve the economy of the people who use the land without sacrificing the sustainability of the function of the greenbelt in supporting reservoir functions.

Based on the explanation on the condition of vegetation in the greenbelt area of the Wonogiri multipurpose reservoir seen from the IVI, teak (Tectona grandis L.) dominates at all levels. Diversity index covers the condition, distribution and stability. The condition of vegetation shows that the current stability of reforestation efforts can now continue. The attitude of the community towards greenbelt is largely supported by reforestation and management even though they still and will use the land without disturbing existing plants. The management should work together with the government and related offices for socialization and community guidance related to reforestation and its utilization.

It is suggested and recommeded to the authorities, namely State-Owned Enterprise of Water Resource Management, that the collaboration with related parties to conduct socialization and guidance to the public is important to bring into reality. Even, there are people who still want to use it better by applying an agroforestry system, where annual crops and annual crops are planted side by side. The trees recommended to be planted in the greenbelt area are fruit or plantation crops such as coffee, but the plants must pass the land suitability. An assessment of several factors such as community behavior, land suitability and economic valuation of the greenbelt, needs to be carried out to determine the steps taken in managing the greenbelt going forward.

\section{CONCLUSIONS}

The condition of vegetation in the greenbelt area of multipurpose reservoir of Wonogiri, seen from the IVI, pinpoints that teak (Tectona grandis L.) leads at all levels of the plant. Diversity index embraces the condition, distribution and stability. The condition of vegetation suggests that the current stability of reforestation efforts can be maintained. The community attitude towards the greenbelt mostly encourages the existence of management even though they still and will use the land without harming the existing plants.

\section{REFERENCES}

Ariani, R., \& Haryati, U. (2018). Sistem alley cropping: analisis SWOT dan strategi implementasinya di lahan kering DAS hulu. Jurnal Sumberdaya Lahan, 12(1), 13-31. http://dx.doi.org/10.21082/jsdl.v12n1.2018.13 $-31$

Azwar, S. (2015). Sikap manusia: teori dan pengukuran. Yogyakarta: Pustaka Pelajar.

BPS-Statistics of Wonogiri Regency. (2019). Wonogiri regency in figures 2019. Wonogiri. Retrieved from https://wonogirikab.bps.go.id /publication/2019/08/16/c429e3c40206c5872 200d544/kabupaten-wonogiri-dalam-angka2019.html

Barbour, M. G., Burk, J. H., \& Pitts, W. D. (1987). Terrestrial plant ecology. New York: The Benjamin/Cummings Publishing Company, Inc.

Bennet, H. (1995). Soil conservation. New York: McGraw-Hill Book Co. Inc.

Cahyanto, T., Chairunnisa, D., \& Sudjarwo, T. (2014). Analisis Vegetasi pohon hutan alam Gunung Manglayang Kabupaten Bandung. Jurnal Istek, 8(2), 145-161. Retrieved from https://journal.uinsgd.ac.id/index.php/istek/art icle/view/225

Decree of Director General of State Owned Enterprise of Water Resource Management 1, D. of D. G. of S. O. E. of W. R. M. Utilization as an asset in P1 PWS Bengawan Solo and Soil of Solo Vallei Werken to be managed by Water Resource Management 1 (2000). Indonesia.

Giliba, R. A., Boon, E. K., Kayombo, C. J., Musamba, E. B., Kashindye, A. M., \& Shayo, 
P. F. (2011). Species composition, richness and diversity in Miombo Woodland of Bereku Forest Reserve, Tanzania. Journal of Biodiversity, 2(1), 1-7. https://doi.org/10. 1080/09766901.2011.11884724

Hadi, S., Budiastuti, S., \& Fajarningsih, R. U. (2019). Biomass and carbon storage of Jor Bay mangrove forest in East Lombok. AIP Conference Proceedings, 2120(1), 040023. https://doi.org/10.1063/1.5115661

Han, H., Huang, C., Ahn, K. H., Shu, X., Lin, L., \& Qiu, D. (2017). The effects of greenbelt policies on land development: Evidence from the deregulation of the greenbelt in the Seoul metropolitan area. Sustainability, 9(7), 1259. https://doi.org/10.3390/su9071259

Hani, A., \& Geraldine, L. P. (2018). Pertumbuhan tanaman semusim dan manglid (Magnolia champaca) pada pola agroforestry. Jurnal Ilmu Kehutanan, 12(1), 172-183. https://doi. org/10.22146/jik.40146

Hani, A., \& Suryanto, P. (2014). Dinamika agroforestry tegalan di perbukitan Menoreh, Kulon Progo, Daerah Istimewa Yogyakarta. Jurnal Penelitian Kehutanan Wallacea, 3(2), 119-128. http://dx.doi.org/10.18330/jwallace a.2014.vol3iss2pp119-128

Hawkins, D., \& Mothersbaugh, D. (2010). Consumer behavior: building marketing strategy, 11th Edition. New York: McGrawHill Book Co. Inc. Retrieved from https:// aclasites.files.wordpress.com/2017/02/consu mer-behavior-building-marketing-strategy11th-edition.pdf

Istomo, I., \& Sari, P. N. (2019). Penyebaran dan karakteristik habitat jenis Rasamal (Altingia excelsa Noronha) di Taman Nasional Gunung Halimun Salak. Jurnal Pengelolaan Sumberdaya Alam Dan Lingkungan (Journal of Natural Resources and Environmental Management), 9(3), 608-625. https://doi.org/ 10.29244/jps1.9.3.608-625

Kusumo, A., Bambang, A. N., \& Izzati, M. (2016). Struktur vegetasi kawasan hutan alam dan hutan rerdegradasi di Taman Nasional Tesso Nilo. Jurnal Ilmu Lingkungan, 14(1), 19-26. https://doi.org/10.14710/jil.14.1.19-26

Maridi, Saputra, A., \& Agustina, P. (2015a). Analisis struktur vegetasi di Kecamatan
Ampel Kabupaten Boyolali. BIOEDUKASI, 8(1), 28-42. https://doi.org/10.20961/bioedu kasi-uns.v8i1.3258

Maridi, Saputra, A., \& Agustina, P. (2015b). Kajian potensi vegetasi dalam konservasi air dan tanah di daerah aliran sungai (DAS): Studi kasus di 3 Sub DAS Bengawan Solo (Keduang, Dengkeng, dan Samin). Prosiding Seminar Nasional Konservasi dan Pemafaatan Sumber Daya Alam, 65-68. Retrieved from https://www.neliti.com/id/publications/17035 4/kajian-potensi-vegetasi-dalam-konservasiair-dan-tanah-di-daerah-aliran-sungai-d

Martono, D. S., Rahayu, S., \& Wijayanti, E. (2019). Vegetation analysis of highland tropical rainforest in the conservation area. IOP Conference Series: Earth and Environmental Science, 347(1), 012005. https://doi.org/10.1088/1755-1315/347/1/012 005

Masria, M., Golar, G., \& Ihsan, M. (2015). Persepsi dan sikap masyarakat lokal terhadap hutan di Desa Labuan Toposo Kecamatan Labuhan Kabupaten Donggala. Warta Rimba, 3(2), 57-64. Retrieved from http://jurnal. untad.ac.id/jurnal/index.php/WartaRimba/arti cle/view/6350

Mayanti, Y. S., Anwar, S., \& Prarikeslan, W. (2018). Sikap dan perilaku masyarakat terhadap hutan di Kawasan TNKS Kecamatan Gunung Tujuh Kabupaten Kerinci. Jurnal Buana, 2(1), 180-191. https://doi.org/ 10.24036/student.v2i1.62

Palupi, T., \& Sawitri, D. R. (2017). Hubungan antara sikap dengan perilaku pro-lingkungan ditinjau dari perspektif theory of planned behavior Proceeding Biology Education Conference, 14(1), 214-217. Retrieved from https://jurnal.uns.ac.id/prosbi/ article/view/18936

Prabowo, S. F. D., Muryani, C., \& Utomowati, R. (2018). Utilization of green belts to Woodland Tourism in support the development of the ecotourism at serbaguna Wonogiri Dams. IOP Conference Series: Earth and Environmental Science, 145(1), 012058. https://doi.org/ 10.1088/1755-1315/145/1/012058

Purnomo, D. W., Usmadi, D., \& Hadiah, J. T. (2018). Dampak keterbukaan tajuk terhadap 
kelimpahan tumbuhan bawah pada tegakan Pinus oocarpa Schiede dan Agathis alba (Lam) Foxw. Jurnal Ilmu Kehutanan, 12(1), 61-73. https://doi.org/10.22146/jik.34121

Rahayu, N. L. D., Sudarmadji, \& Faida, L. R. W. (2016). Pengaruh vegetasi kawasan sabuk hijau (green belt) Waduk Sermo Kulon Progo terhadap kenampakan hasil proses erosi dan pemanfaatan oleh masyarakat. Majalah GEOGRAFI Indonesia, 30(1), 76-87. https:// doi.org/10.22146/mgi.15625

Rusdiana, R., Malik, A., \& Ramlah, S. (2017). Sikap masyarakat dalam pengelolaan hutan pasca kegiatan reboisasi di Kelurahan Lambara Kecamatan Palu Utara Kota Palu. Warta Rimba, 5(1), 6-12. Retrieved from http://jurnal.untad.ac.id/jurnal/index.php/Wart aRimba/article/view/8672

Sari, Y. P., Salampessy, M. L., \& Lidiawati, I. (2018). Persepsi masyarakat pesisir dalam pengelolaan ekosistem hutan mangrove di Muara Gembong Bekasi Jawa Barat. Perennial, 14(2), 78-85. http://dx.doi.org/ 10.24259/perennial.v14i2.5303

Setiawan, H., Purwanti, R., \& Garsetiasih, R. (2017). Persepsi dan sikap masyarakat terhadap konservasi ekosistem mangrove di Pulau Tanakeke Sulawesi Selatan. Jurnal Penelitian Sosial Dan Ekonomi Kehutanan, 14(1), 57-70. Retrieved from https://www. neliti.com/id/publications/125180/persepsidan-sikap-masyarakat-terhadap-konservasiekosistem-mangrove-di-pulau-ta

Sujana, K., \& Hariyadi, S. (2018). Hubungan antara sikap dengan perilaku peduli lingkungan pada mahasisiwa. Jurnal Ecopsy, 5(2), 81-87. Retrieved from https://ppjp. ulm.ac.id/journal/index.php/ecopsy/article/vie w/5026

Surati, S. (2014). Analisis sikap dan perilaku masyarakat terhadap Hutan Penelitian Parung Panjang. Jurnal Penelitian Sosial dan Ekonomi Kehutanan, 11(4), 339-347. Retrieved from https://media.neliti.com/media /publications/29106-ID-analisis-sikap-danperilaku-masyarakat-terhadap-hutan-peneliti an-parung-panjang.pdf

Suyamto, S. (2011). Struktur komunitas dan pemanfaatan bambu dalam perspektif masyarakat Kecamatan Srumbung Kabupaten Magelang Provinsi Jawa Tengah [TESIS]. Fakultas Matematika dan Ilmu Pengetahuan Alam Program, Pascasarjana, Universitas Indonesia. Retrieved from http://lib.ui.ac.id/ file?file=digital/20294757-T29861-Struktur\% 20komunitas.pdf

Tjandra, E. A., \& Tjandra, S. R. (2013). Hubungan antara komponen kognitif, komponen afektif dan komponen perilaku terhadap sikap konsumen memanfaatkan teknologi internet. Jurnal Manajemen, 17(1), 42-52. Retrieved from http://digilib.mercu buana.ac.id/manager/t!@file_artikel_abstrak/I si_Artikel_359518765570.pdf

Ufiza, S., Salmiati, S., \& Ramadhan, H. (2018). Analisis vegetasi tumbuhan dengan metode kuadrat pada habitus herba di Kawasan Pegunungan Deudap Pulo Nasi Aceh Besar. Prosiding Seminar Nasional Biotik, 5(1), 209215. Retrieved from https://jurnal.ar-raniry. ac.id/index.php/PBiotik/article/view/4258

Widiatmaka, Mediranto, A., \& Widjaja, H. (2015). Karakteristik, klasifikasi tanah, dan pertumbuhan tanaman jati (Tectona grandis Linn f.) Var. unggul nusantara di Ciampea, Kabupaten Bogor. Jurnal Pengelolaan Sumberdaya Alam Dan Lingkungan, 5(1), 8797. Retrieved from https://journal.ipb.ac.id/ index.php/jpsl/article/view/10210

Wiryantara, I. W. G., Wijaya, G., \& Suarna, I. W. (2014). Analisis vegetasi sebagai dasar pengembangan agroforestri di DAS mikro Desa Tukad Sumaga, Kecamatan Gerokgak, Kabupaten Buleleng. Agrotrop: Journal on Agriculture Science, 4(1), 89-98. Retrieved from https://ojs.unud.ac.id/index.php/agrotrop /article/view/13636

Ziliwu, Y. (2002). Pengaruh beberapa macam tanaman terhadap aliran permukaan dan erosi [Masters Thesis]. Program Pasca Sarjana, Universitas Diponegoro. 